\title{
Tunable Assembly of Peptide-coated Gold Nanoparticles
}

\author{
Jennifer A. Tullman • William F. Finney • Yu-Jen Lin • \\ Sandra Whaley Bishnoi
}

Received: 22 January 2007 / Accepted: 6 July 2007 / Published online: 10 August 2007

(C) Springer Science + Business Media, LLC 2007

\begin{abstract}
The interaction between peptides and gold surfaces has increasingly been of interest for bionanotechnology applications. To more fully understand how to control such interactions, we have studied the optical properties of peptide-modified gold nanoparticles as a function of peptide composition, $\mathrm{pH}$ of the surrounding medium, and peptide concentration. We show using localized surface plasmon resonance, transmission electron microscopy, and surface-enhanced Raman scattering (SERS) that selected "gold-binding peptides" (GBPs), similar to those isolated for binding to gold films using yeast display, can bind to gold nanoparticles at a variety of pHs. Peptide modifications of nanoparticles can lead to irreversible particle aggregation when the $\mathrm{pH}$ of the solution is kept below the isoelectric point $(\mathrm{pI})$ of the peptide. However, at pHs above the peptide's pI, particles remain stable in solution, and peptides remain bound to the particles possibly through amine coordination of gold. Additionally, we demonstrate the potential in using SERS for the direct detection of GBPs on gold-silica nanoshells, eliminating the need for indirect labeling methods.
\end{abstract}

Keywords Peptide $\cdot$ Gold $\cdot$ Nanoparticles $\cdot$ Assembly

J. A. Tullman • W. F. Finney • Y.-J. Lin · S. W. Bishnoi $(\varangle)$ Department of Biological, Chemical, and Physical Sciences, Illinois Institute of Technology,

3101 S. Dearborn St.,

Chicago, IL 60616, USA

e-mail: bishnoi@iit.edu

J. A. Tullman

Department of Chemical and Biomolecular Engineering,

Johns Hopkins University,

Baltimore, MD, USA

\section{Introduction}

Over the last decade, many groups have specialized in the isolation of peptides with molecular specificity to inorganic materials such as metals, metal oxides, and semiconductors [1-3]. Using biological/combinatorial libraries, based on the deoxyribonucleic acid manipulation of an organism (virus/phage, bacteria, or yeast) to produce random peptides on the exterior of the organism, peptides with high affinities and specificities to inorganic surfaces have been isolated. These peptides have then been used for the organization of nanostructures on the exterior of viruses [4]. The composition of the amino acid sequences isolated using combinatorial methods can vary widely with the type of library (phage, yeast, or bacterial) used in the selection process, as seen in the selection of peptides for the surface of gold [5]. Some "gold-binding peptides" (GBPs) have shown high levels of specificity for gold binding, while others have cross-reactivity with other metallic and metal oxide surfaces. To date, a consensus sequence for gold binding has not been isolated using these combinatorial methods, and the overall basis for the peptide-surface interactions (electrostatic, coordination, and/or van der Waals forces) is still not understood. The work of Willett et al. [6] suggested that the electrostatic charge of the peptides may play a role in the binding affinity between various materials and the peptides selected. In this study, we will control the extent of particle aggregation by controlling the electrostatic charge of peptide-modified gold nanoparticles.

Plasmonic materials such as gold nanoparticles are used for biological sensing and the study of protein-protein interactions by monitoring the collective electronic excitations, also known as particle plasmon resonances or localized surface plasmon resonance (LSPR). For gold nanoparticles, these plasmon resonances are observed as a 
strong absorption around $520 \mathrm{~nm}$ for individual nanoparticles. A red shift in the optical extinction spectrum is due to near-field coupling between individual particle plasmons, with the magnitude of the red shift dependent on the extent of aggregation and interparticle distances [7, 8]. Various biosensors have been constructed by monitoring changes in the LSPR at $520 \mathrm{~nm}$ upon the introduction of analytes to gold colloid solutions [9-11]. The shift in the LSPR has also been used to study the reversible assembly of 8.5 -nm gold nanoparticles modified with thiolated coiled-coil peptides [12].

Surface-enhanced Raman scattering (SERS) is another technique that uses gold nanoparticles for biological sensing. SERS uses the electromagnetic field from the surface plasmon to electromagnetically enhance (on the order of $10^{6}$ to $10^{10}$ ) the vibrational spectrum of a molecule in close proximity to the metal $[13,14]$. One benefit from using SERS in addition to surface plasmon resonance (SPR) is the detection of a peptide's unique spectroscopic fingerprint. Additionally, other information may be obtained using SERS, such as the molecular orientation and surface coverage of molecules bound to the gold surface [15].

In this letter, we suggest a generalized method for controlling the assembly of peptide-modified gold nanoparticles as determined through the use of SPR and transmission electron microscopy (TEM). The sensitivity of the gold colloid plasmon to changes in the extent of particle aggregation has been utilized in detecting the affect of a peptide binding to gold at concentrations as low as $0.05 \mu \mathrm{g} / \mathrm{mL}$. We have also found that the subsequent peptide-induced aggregation of gold nanoparticles can be directed through control of the local $\mathrm{pH}$, which may prove useful in future bionanotechnology applications. We have found SERS to be useful for the detection of nonaggregationinducing peptides on gold nanoparticle surfaces and discuss the possibility of using SERS to investigate peptide-binding mechanisms.

\section{Experimental}

Biotinylated custom peptides were synthesized and purified by American Peptide (Sunnyvale, CA). Correct synthesis and purity $(>90 \%)$ was verified using reverse-phase highpressure liquid chromatography and electrospray mass spectrometry. Silica nanoparticles $(\sim 100 \mathrm{~nm}$ in diameter) were obtained from Precision Colloid, LLC. Aminopropyl triethoxysilane (APTES) was purchased from Gelest. All other chemicals were purchased from Sigma-Aldrich (St. Louis, MO) and used as received. Gold nanoparticles (colloid) were synthesized using the Turkevich method [16]; briefly, $1 \mathrm{~mL}$ of $29.7 \mathrm{mM} \mathrm{HAuCl}{ }_{4}$ was added to
$100 \mathrm{~mL}$ of Milli-Q water (Millipore, $18 \mathrm{M} \Omega$ ) and brought to a boil, then $1.5 \mathrm{~mL}$ of $34 \mathrm{mM}$ sodium citrate was added, and the solution continued to boil for $10 \mathrm{~min}$. Particles were characterized using visible ultraviolet (UV-Vis) spectroscopy (JASCO, V-530), dynamic light scattering (DLS, Malvern Zetasizer Nano-S), and TEM (JEOL 3010 microscope operating at $300 \mathrm{kV}$ ). Samples were prepared by mixing $1 \mathrm{~mL}$ of peptide solution with $3 \mathrm{~mL}$ of gold colloid (absorbance $=0.53$ at $520 \mathrm{~nm}, \sim 9.7 \times 10^{10}$ particles) for a final peptide concentration of $0.7 \mu \mathrm{g} / \mathrm{mL}$ and final ionic strength of $10 \mathrm{mM}$ phosphate buffer (PB), $\mathrm{pH}$ 7. To prepare TEM samples, peptides were incubated with gold for $30 \mathrm{~min}$, drops of the resulting solutions were floated on carbon coated copper TEM grids, the grids were allowed to dry for $1 \mathrm{~min}$, and then excess solution was blotted off. The average gold particle size was $23.3 \mathrm{~nm}( \pm 0.6)$ according to TEM measurements $(N=50)$. Buffers used in all experiments were made with extreme care as high ionic strength buffers can cause the negatively charged colloid to aggregate. Citrate ( $\mathrm{pH} 5$ and 7), phosphate ( $\mathrm{pH} 7)$, and carbonate $(\mathrm{pH}$ 10.7) buffers were all used at or below $40 \mathrm{mM}$ concentrations to maintain buffering capacity but reduce ionic strength.

Peptide charges were calculated at various $\mathrm{pHs}$ based on the acid dissociation constants of the individual amino acids and the $\mathrm{C}$ terminus (Table 1) [17]. Because the $\mathrm{N}$ terminus of the peptides are biotinylated, there was no $\mathrm{N}$ terminus included in calculating the pI, and only the charged amino acids (histidine and lysine) and the $\mathrm{C}$ terminus contributed to the overall peptide charge.

To test peptide binding to gold when peptides are negatively charged, (1) P44 and P45 peptides at a final concentration of $0.7 \mu \mathrm{g} / \mathrm{mL}$ in $40 \mathrm{mM}$ PB were incubated with gold colloid at $\mathrm{pH} 7(\mathrm{P} 44$ charge $=+1.27, \mathrm{P} 45$ charge $=-0.73$, Table 1) or $\mathrm{pH} 11$ (charges of -0.23 and -1.0 , respectively), (2) excess peptide was removed by centrifugation for $2 \mathrm{~min}$ at 10,000 rpm in an Eppendorf MiniSpin microcentrifuge, and (3) peptide-modified particles were resuspended with 10 $\mathrm{mM}$ PB at either $\mathrm{pH} 4(\mathrm{P} 44$ charge $=+4.0, \mathrm{P} 45$ charge $=+2.0)$

Table 1 Peptide sequences and their charges as a function of $\mathrm{pH}$

\begin{tabular}{llllll}
\hline Peptide name & Sequence & pI & \multicolumn{3}{c}{ peptide charge at } \\
\cline { 3 - 6 } & & & pH 5 & pH 7 & pH 11 \\
\hline P14 & $\begin{array}{c}\text { Biotin- } \\
\text { KHKHFHF }\end{array}$ & 10.60 & +3.74 & +1.27 & -0.23 \\
P44 & $\begin{array}{c}\text { Biotin- } \\
\text { KHKHWHW }\end{array}$ & 10.60 & +3.74 & +1.27 & -0.23 \\
P45 & $\begin{array}{c}\text { Biotin- } \\
\text { AHAHAHA }\end{array}$ & 6.50 & +1.74 & -0.73 & -1.00 \\
P46 & $\begin{array}{c}\text { Biotin- } \\
\text { FHFHFHF }\end{array}$ & 6.50 & +1.74 & -0.73 & -1.00 \\
& & & & & \\
\hline
\end{tabular}


or $\mathrm{pH}$ 11. UV-Vis spectra were taken immediately after resuspension to monitor the degree of flocculation. A control sample was also made by interacting nanoparticles with only $40 \mathrm{mM} \mathrm{PB}(\mathrm{pH} 7$ or 11) and then completing the centrifugation steps to monitor particle loss and inadvertent aggregation because of the centrifugation process. Each experiment was conducted in triplicate, and the averages are shown (Fig. 4a-d).

Gold silica nanoshells were synthesized by modifying the protocol from the study of Oldenburg et al. [18]; namely, prefabricated silica cores with diameters of $100 \mathrm{~nm}$ (Precision Colloids, LLC) were transferred from water into ethanol through the formation and distillation of the ethanol-water aziotrope. The resulting 4-wt.\% solution of silica in $95 \%$ ethanol was modified with $\sim 500 \mu \mathrm{L}$ of APTES for $30 \mathrm{~mL}$ of silica cores, and the solution was incubated overnight. Modified cores were boiled, and excess APTES was removed through centrifugation of the particles. All other steps were followed from literature [18].

SERS substrates were prepared by silanizing glass microscope slides through the deposition of APTES onto precleaned glass slides. Slides were then covered with a hydrophobic mask (Invitrogen, S-24737), and $\sim 100 \mu \mathrm{L}$ of nanoparticles were pipeted into the wells. The particles were allowed to settle overnight. The next day, the remaining solution was removed, and the substrate was air dried. To obtain the SERS spectra of peptide P46 (Fig. 5b), a $100-\mu \mathrm{L}$ aliquot of $10 \mu \mathrm{g} / \mathrm{mL}$ solution of $\mathrm{P} 46$ in $\mathrm{PB}$ was incubated on the gold nanoshell substrate. After incubation, the overlayer of solution was removed, and the substrate was rinsed with buffer to remove unbound peptide, and the surface was dried in air.

SERS spectra were collected using a Renishaw inVia spectrometer system through a 50X/NA 0.75 objective at $180^{\circ}$. For each measurement, an integration time of $90 \mathrm{~s}$ was used after exciting with approx. $150 \mu \mathrm{W}$ of $785-\mathrm{nm}$ light from a diode laser. Five spectra were averaged to create each Raman spectral trace shown.

\section{Results and discussion}

Three peptides (P44, P45, and P46) were chosen from the literature [2] for their affinity to gold films as demonstrated using a yeast display system. The binding of the peptides was previously quantified by Belcher et al. [2] using optical microscopy to image yeast modified with the peptide sequences on gold films. In their studies, yeast modified with the P44 sequence (Table 1) showed a strong binding affinity to gold films, while those with the P45 and P46 sequences had intermediate and low affinities for gold, respectively. The proposed origin of P44's affinity was the interaction of the gold surface with the amino acid tryptophan (symbolized: W), while phenylalanine (symbolized: F) presumably reduced binding in P46. To investigate this proposed mechanism, we created a fourth peptide containing the same sequence as P44 except substituting F for W (P14) (Table 1).

The overall ionic charge on a peptide is dependent on the composition of the individual amino acids that make up the peptide (Table 1) and the $\mathrm{pH}$ of the solution. Because of the presence of two lysine residues per peptide $\left(\mathrm{p} K_{\mathrm{a}}\right.$ of 10.5), the peptide charges for $\mathrm{P} 14$ and $\mathrm{P} 44$ at $\mathrm{pH} 7$ are significantly different than those for P45 and P46. P45 and P46 both contain $50 \%$ histidine residues $\left(\mathrm{p} K_{\mathrm{a}} 6.0\right)$, but because they lack the lysine residue, both have a negative charge at $\mathrm{pH}$ 7. The lysine and histidine residues have been previously shown to participate in metal binding either through electrostatic interaction when they exist in their charged states or through the coordination of gold by amine functional groups in their neutral states [19].

We used SPR shifts in the gold colloid to monitor colloid stability after the addition of peptides to gold nanoparticles in the solution, with a final peptide concentration of $0.7 \mu \mathrm{g} / \mathrm{mL}$ (Fig. 1, inset). When added to the colloid at $\mathrm{pH} 7$, peptides $\mathrm{P} 44$ and $\mathrm{P} 14$ cause an immediate color change from red to blue, and a second peak was formed at $\sim 650 \mathrm{~nm}$ (Fig. 1a,b-inset), signifying significant aggregation of nanoparticles. The color of colloid remained the same with the addition of $\mathrm{P} 46$ peptides at $\mathrm{pH} 7$ (Fig. 1d, inset), and no shift from the original colloid spectrum was seen at $\mathrm{pH}$ 7. A slight shoulder at $\sim 550 \mathrm{~nm}$ was observed with the addition of the $\mathrm{P} 45$ peptide to the gold colloid at pH 7 (Fig. 1c, inset). These samples were analyzed using TEM to determine the extent of particle aggregation (Fig. 1a-d). According to the TEM results, those gold nanoparticles exposed to the $\mathrm{P} 14$ and $\mathrm{P} 44$ peptides had a large degree of aggregation (Fig. 1a,b) with significant particle overlap, while those particles exposed to P45 and P46 (Fig. 1c,d) formed smaller clusters according to TEM with greater interparticle spacing than P44- and P14-coated nanoparticles. The clusters seen in TEM for P45- and P46modified particles were not detected in the solution using either DLS or UV-Vis, except after the particles had interacted with the peptides for more than $1 \mathrm{~h}$. This suggests that the clusters seen by TEM may form because of (1) drying effects, (2) formation of a stabilizing coating to the colloid upon P45 and P46 binding, similar to that seen in histidine-rich epitope-stabilized nanoclusters [19], or (3) a difference in the adsorption kinetics of a positively charged vs negatively charged peptide, similar to that seen in charged alkanethiols [20].

Two possible mechanisms explain the rapid aggregation of nanoparticles from the addition of the P14 and P44 peptides. First, the peptides may bind to more than one particle at a time, leading to an effect called "bridging" 

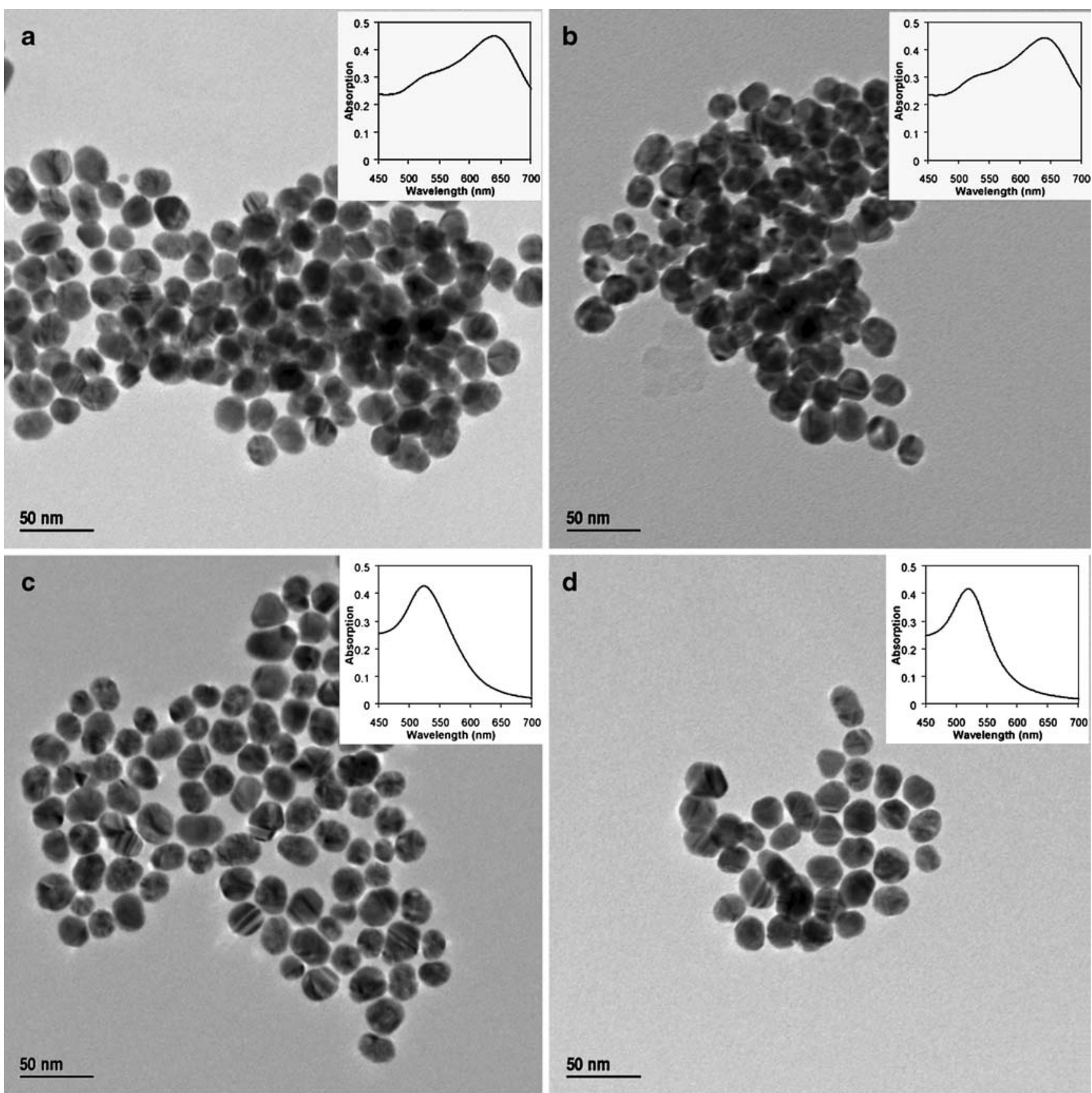

Fig. 1 Representative TEM images of the peptide-modified gold colloid and corresponding UV-Vis spectra. a Aggregates of P14 peptide and b P44-modified colloid at $\mathrm{pH} 7$ with UV-Vis of solutions after 15 min of interaction (inset). c Clusters of P45 and d P46-modified gold

flocculation [21]. This effect has been used to control the interparticle spacing of aggregated gold colloid through the folding of a helix-loop-helix-forming polypeptide on the particle's surface [22]. Or, a second possibility is that the addition of positively charged peptides to negatively charged gold particles decreases electrostatic repulsion from the electrical double layer (EDL) on the particles allowing colliding particles to aggregate. This second effect is commonly seen when the ionic concentration of gold colloid

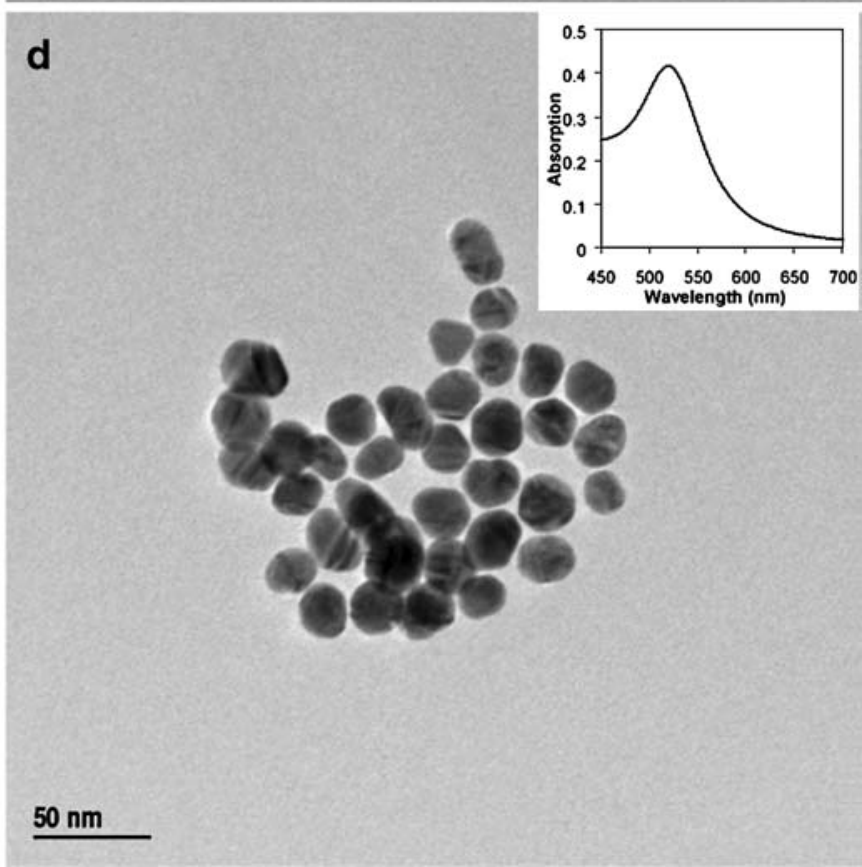

colloid at $\mathrm{pH} 7$ with corresponding UV-Vis of solutions after $15 \mathrm{~min}$ of interaction (inset). Images were collected on a JEOL 3010 TEM microscope operating at $300 \mathrm{kV}$, particle size $=23.3 \pm 0.6 \mathrm{~nm}, N=53$ particles. Peptide concentration $=0.7 \mu \mathrm{g} / \mathrm{mL}$

solutions is increased through the addition of electrolytes $[21,23]$. If the aggregation seen in P14- and P44-modified particles is due to "bridging" flocculation, then increasing peptide concentration should decrease the aggregation because the particle surface will be saturated with individual peptides, preventing "bridging" flocculation. If a reduction in electrostatic repulsions dominates, then the degree of particle aggregation should increase with peptide concentration. 
To determine which mechanism is responsible for particle aggregation, the particle concentration was held constant, and increasing concentrations of P44 and P45 peptides in $10 \mathrm{mM} \mathrm{PB}$ were interacted with the particles
(Fig. 2). P14 and P44 behaved similarly to one another, as did P45 and P46 peptides, in the previous experiments; therefore, only P44 and P45 were tested further. The flocculation tendencies of particles modified with these
Fig. 2 Affect of peptide concentration on the plasmon excitation wavelength for peptide-modified gold nanoparticles. Gold nanoparticle absorption spectra after modification with a P44 and b P45 Peptides at $\mathrm{pH}$ 7. The following final peptide concentrations are shown: $10.05,20.10,30.30$, and $40.70 \mu \mathrm{g} / \mathrm{mL}$. c Plasmon resonance wavelength as a function of peptide concentration for P44- and P45-modified particles
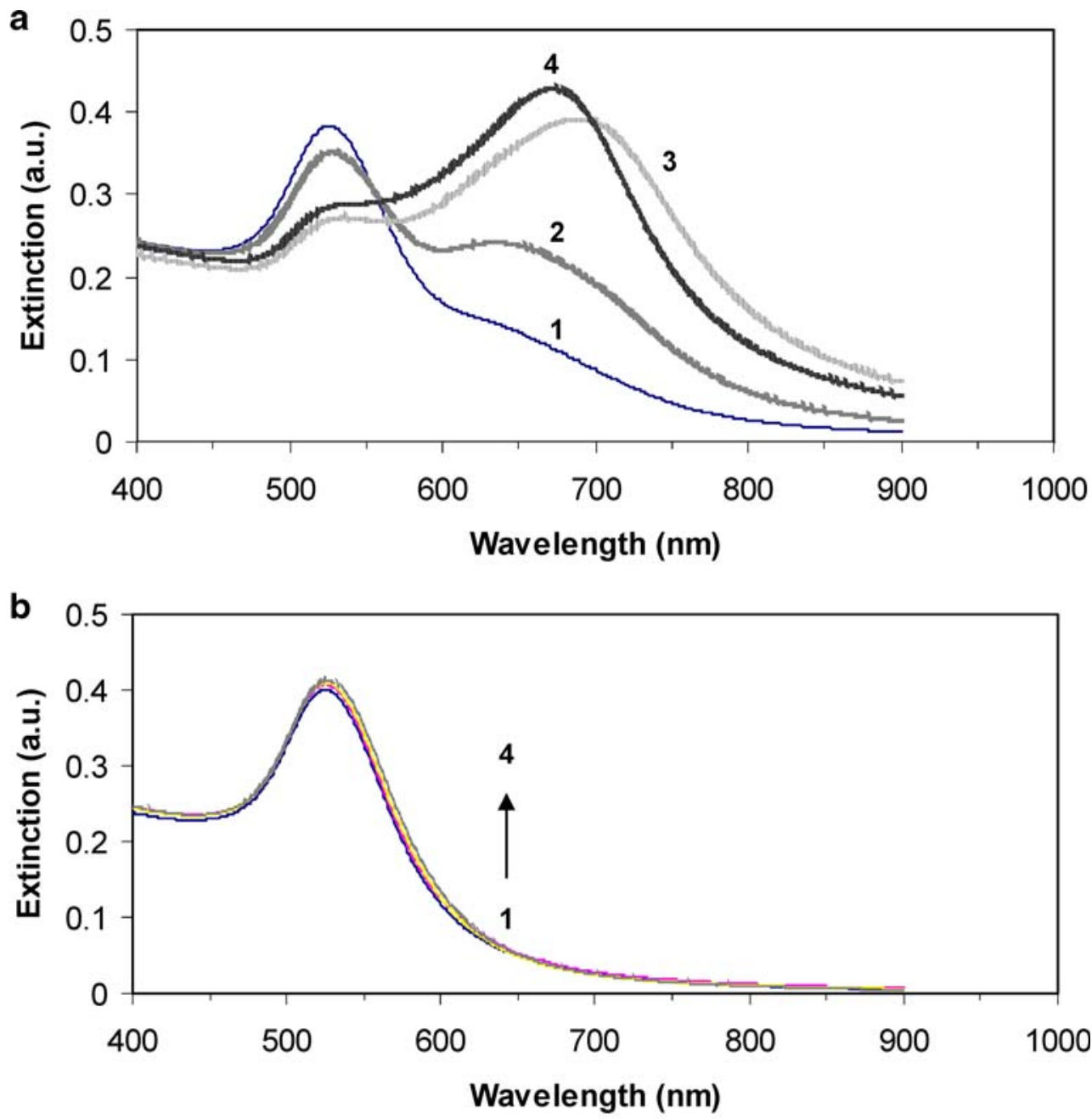

C

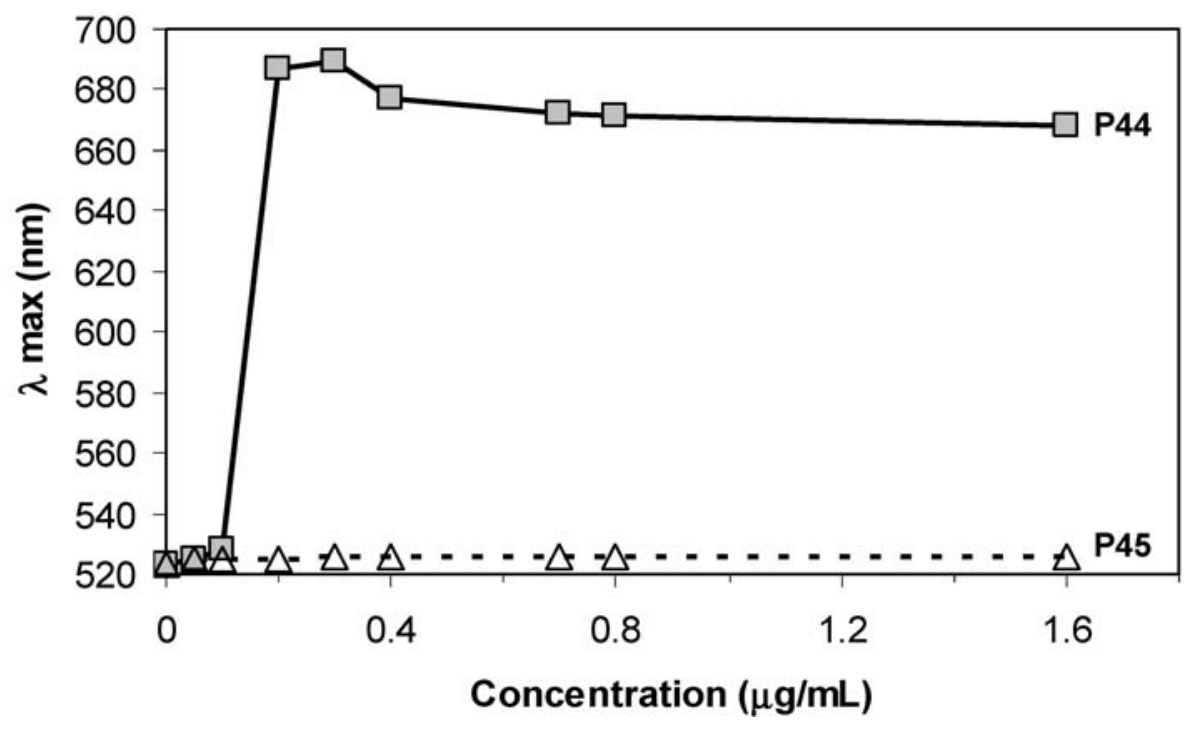


two peptides were compared to one another because their isoelectric points vary significantly (Table 1 ), while their average Hopp-Woods hydrophobicities are similar to one another ( -0.3 and -0.5 , respectively) [24]. The extent of particle aggregation was seen to increase with $\mathrm{P} 44$ peptide concentration as can be seen from the shift in the wavelength of maximum absorption as a function of peptide concentration (Fig. 2a,c). The maximum plasmon position for a P44 concentration of $0.05 \mu \mathrm{g} / \mathrm{mL}$ was at $525 \mathrm{~nm}$ with a shoulder developing at $645 \mathrm{~nm}$ (Fig. 2a,c). This position shifts to 528 $\mathrm{nm}$ with a larger shoulder at $647 \mathrm{~nm}$ at a P44 concentration of $0.10 \mu \mathrm{g} / \mathrm{mL}$. The aggregate plasmon $(\sim 670 \mathrm{~nm})$ dominates at $\mathrm{P} 44$ concentrations greater than or equal to $0.20 \mu \mathrm{g} / \mathrm{mL}$, which corresponds to a coverage of $\sim 2.3 \times$ $10^{14}$ molecules $/ \mathrm{cm}^{2}$ (Fig. 2c). This coverage is similar to that found by Kirk and Bohn for the binding of the peptide CKWAKWAK to the gold colloid $\left(3.1 \times 10^{14}\right)$ using fluorescence difference measurements [25]. Once the particle's surface is fully covered with peptide, the further addition of peptide would not be expected to have an effect on the particle's stability in solution. This was evident from the stabilization of the $\lambda_{\max }$ around $670 \mathrm{~nm}$ above $0.4 \mu \mathrm{g} / \mathrm{mL}$ or $\sim 4.7 \times 10^{14}$ molecules $/ \mathrm{cm}^{2}$ (Fig. $2 \mathrm{c}$ ). Howev$\mathrm{er}$, the presence of excess peptide may affect the kinetics of peptide binding with increasing peptide concentrations increasing the rate of conjugation between the peptide and gold surface [20].

For those particles that interacted with P45, the plasmon wavelength was constant at $525 \mathrm{~nm}$ (Fig. 2b) independent of peptide concentration, but there was a slight increase in the intensity of the LSPR peak upon peptide binding. The source of this increase is unclear but may be due to (1) the stabilization of the colloid in buffer solutions upon P45 binding or (2) a change in the local dielectric permittivity upon peptide binding as was seen upon binding of the thiolated peptide CALNN to the gold colloid [23].

The average hydrodynamic diameter $\left(D_{\mathrm{H}}\right)$ for each sample in Fig. 2 was also monitored using DLS. For particles interacted with the $\mathrm{P} 44$, the $D_{\mathrm{H}}$ increased from $67 \pm 2 \mathrm{~nm}$ at $0.05 \mu \mathrm{g} / \mathrm{mL}$ to $2,087 \pm 482 \mathrm{~nm}$ at $0.70 \mu \mathrm{g} / \mathrm{mL}$. However, for particles that interacted with the P45 peptide, the $D_{\mathrm{H}}$ was consistent $(35 \pm 12 \mathrm{~nm})$ over the entire peptide concentration range tested. These results lead to the conclusion that the flocculation seen at $\mathrm{pH} 7$ for P14 and P44 is due to the reduction in electrostatic repulsion between negatively charged particles from the addition of positively charged peptides (Table 1). The addition of positively charged peptides destabilizes the negatively charged particles leading to particle aggregation with larger aggregates forming with increasing peptide concentration. These peptides must be attracted to the gold surface through electrostatic interactions because the addition of small electrolytes at much higher concentrations have no obvious effect on the plasmon resonance of the gold colloid at $523 \mathrm{~nm}$ (Fig. 2, $0 \mu \mathrm{g} / \mathrm{mL}$ peptide in $10 \mathrm{mM} \mathrm{PB}$ ).

Because the $\mathrm{pI}$ (or the $\mathrm{pH}$ at which the peptide charge equals zero) of P45 and P46 differ significantly from P44 and P14 (Table 1), we hypothesized that the degree of gold colloid flocculation could be controlled through manipulation of a peptide's overall ionic charge. Because both P14 and P44 peptides are composed of $71 \%$ basic residues $(\mathrm{K}, \mathrm{H})$, their overall ionic charge is positive until a $\mathrm{pH}$ greater than 10.6 is reached, while the charges on P45 and $\mathrm{P} 46$ are primarily negative until the $\mathrm{pH}$ is reduced below 6.5. Further studies were conducted with all four peptides at varying $\mathrm{pHs}$ to determine whether the degree of colloid flocculation could be engineered by controlling peptide charge. The results (Fig. 3) demonstrate that when the $\mathrm{pH}$ is raised above the $\mathrm{pI}$ of any of the peptides tested (i.e. peptide was negatively charged), the colloid remained stable, and the maximum absorption was at $\sim 520 \mathrm{~nm}$. Conversely, when the $\mathrm{pH}$ was held below the $\mathrm{pI}$ of any of the peptide tested (i.e., peptide was positively charged), a significant aggregation of the colloid occurred, and the maximum absorption was red shifted to $\sim 630 \mathrm{~nm}$. Thus, by adjusting the overall $\mathrm{pH}$ to achieve the appropriate charge on a particular peptide, we can control the flocculation of the colloid. However, the peptide-induced flocculation of the gold colloid was irreversible. Particles could not be restabilized by raising the $\mathrm{pH}$ above the $\mathrm{pI}$ after the peptide was bound to the colloid or by resuspending the peptideparticle aggregates into fresh $2 \mathrm{mM} \mathrm{PB}$ at $\mathrm{pH} 11$. This new instability suggests that the adsorption of the positively

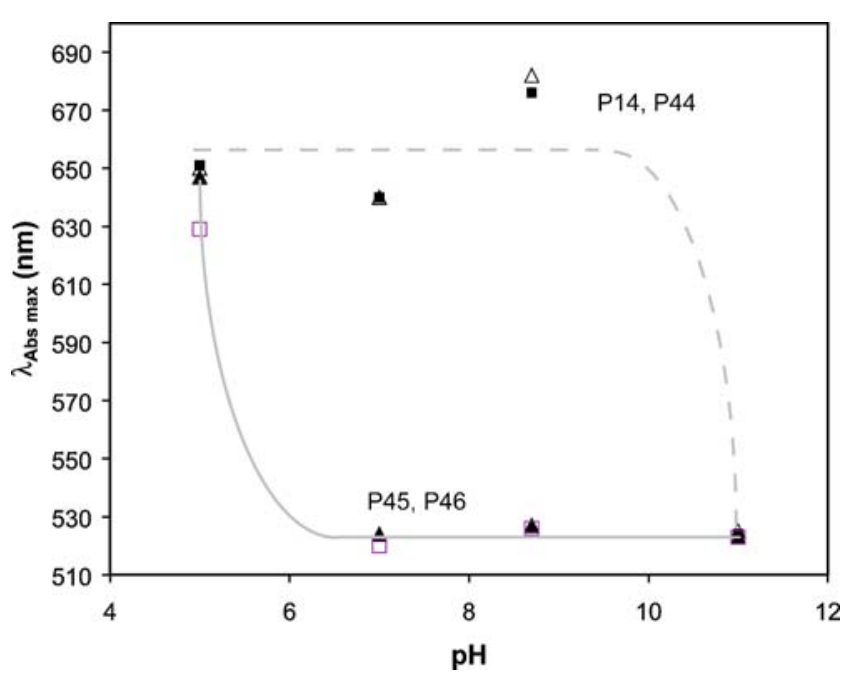

Fig. 3 Wavelength of absorption maximum vs $\mathrm{pH}$. The resulting maximum plasmon wavelength for particles modified with $0.7 \mu \mathrm{g} / \mathrm{mL}$ of P14, P44- and P45, P46-modified particles. The $\mathrm{pH}$ was controlled through the use of $2 \mathrm{mM}$ citrate buffers ( $\mathrm{pH} 5$ and 7) or $2 \mathrm{mM}$ carbonate buffer ( $\mathrm{pH} 11)$. P14, P44-modified particles (dashed line) and P45, P46-modified particles (solid line) 
charged peptides has permanently disrupted the EDL, preventing the coulombic repulsion that stabilizes colloids.

The previous experiments were insufficient to determine whether peptides were bound to gold at $\mathrm{pHs}$ above their isoelectric points; therefore, we examined the degree of flocculation of peptides as a function of $\mathrm{pHs}$ after the removal of excess peptide (Fig. 4). The particles were interacted with $\mathrm{P} 44$ and $\mathrm{P} 45$ peptides at $\mathrm{pH} 7$, excess peptide was removed through centrifugation, and peptides were resuspended in either $10 \mathrm{mM} \mathrm{PB}$ at $\mathrm{pH} 4$ (Fig. 4a) or 11 (Fig. 4b). The binding of $\mathrm{P} 44$ at $\mathrm{pH} 7$ was previously demonstrated to lead to flocculation of the gold solution (Figs. 1, 2, and 3). When those particles are centrifuged to remove excess peptide, many of the particles are lost in centrifugation as was apparent from the reduced absorbance of P44 in Fig. 4a, b. For those modified particles successfully brought back into solution, the modification with P44 at $\mathrm{pH} 7$ led to irreversible particle aggregation, as the aggregate plasmon dominated even when the $\mathrm{pH}$ was raised to 11 (Fig. 4b). Previously, it was shown that the modification with the P45 peptide did not lead to particle flocculation at $\mathrm{pH} 7$ (Figs. 1, 2, and 3), but it was unclear whether this was due to the negative peptide charge on the gold surface at this $\mathrm{pH}$ or due to the lack of peptide affinity for gold at $\mathrm{pHs}$ above their $\mathrm{pI}$. When the particles were modified with P45, excess peptide removed from the solution, and then the particles resuspended in $\mathrm{pH} 4$ buffer, the particles became aggregated (Fig. 4a). This result was similar to that seen previously in the presence of excess peptide (Fig. 3), confirming that $\mathrm{P} 45$ peptides do bind to the gold surface at $\mathrm{pH} \mathrm{7,} \mathrm{although} \mathrm{their} \mathrm{overall} \mathrm{charge} \mathrm{is}$ expected to be negative. Particles modified with P45 and then resuspended in $\mathrm{pH} 11$ buffer were resuspended with only a moderate degree of aggregation from the centrifugation step (Fig. 4b).

To determine whether the P44 peptide will also conjugate to the gold surface above its $\mathrm{pI}$, the P44 and $\mathrm{P} 45$ peptides were incubated with gold nanoparticles at $\mathrm{pH}$ 11 , and then excess peptide was removed through centrifugation. The supernatant with excess peptide was removed, and the pellet containing gold particles was resuspended at either $\mathrm{pH} 4$ (Fig. 4c) or 11 (Fig. 4d). As expected, both the P44- and P45-modified particles aggregated when resuspended in the $\mathrm{pH} 4$ buffer (Fig. 4c) because this is below both peptides' pI, while the control particles (no peptide) had only minor aggregation. When resuspended at $\mathrm{pH} \mathrm{11,} \mathrm{both} \mathrm{the} \mathrm{P44-} \mathrm{and} \mathrm{P45-modified}$ peptides were successfully brought back into solution (Fig. 4d) with minimal loss of particles relative to the control. We assume that the peptide coverage on the particles in Fig. $4 \mathrm{c}, \mathrm{d}$ is the same within experimental error, which means that the stability seen in previous experiments (Fig. 3) above a peptide's $\mathrm{pI}$ was probably due to the charge on the peptide and not differences in peptide coverages at different $\mathrm{pHs}$.

Although this experiment confirms that both P44 and P45 peptides will bind to the gold surface at pHs above their isoelectric point, it does not address possible coverage differences because of the $\mathrm{pH}$ of peptide interaction. Additional work is underway to quantify the peptide coverages as a function of $\mathrm{pH}$ using fluorescence difference spectroscopy and SERS.

The colloidal flocculation of gold in the presence of charged peptide species was used as a test for successful peptide binding, possibly through electrostatic interactions.
Fig. 4 UV-Vis study on stability of peptide-modified nanoparticles upon removal of excess peptides. a, b Nanoparticles incubated with buffer (control), $\mathrm{P} 44$ or $\mathrm{P} 45$ peptides at $\mathrm{pH} 7$, excess peptide removed through centrifugation, and then particles resuspended in $10 \mathrm{mM}$ phosphate buffer at $\mathrm{pH} 4$ (a) or 11 (b). c, d Nanoparticles incubated with phosphate buffer (control), P44 or P45 peptides at $\mathrm{pH} 11$, excess peptide removed through centrifugation, and then particles resuspended in either $\mathrm{pH} 4$ (c) or 11 (d) $10 \mathrm{mM}$ phosphate buffer
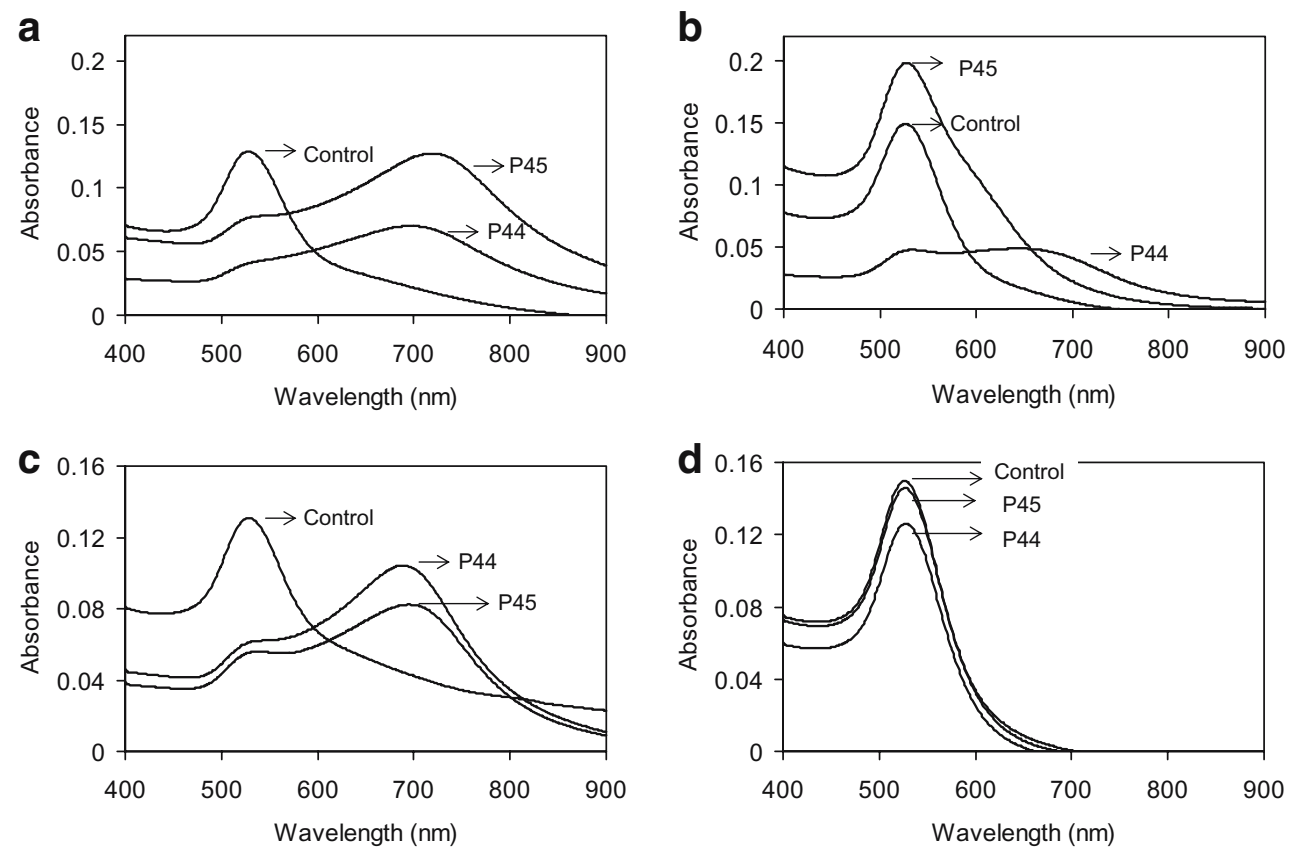
Because the P45 and P46 peptides do not cause such a dramatic change to the plasmon excitation wavelengths at neutral $\mathrm{pH}$, another method is needed for the detection of neutral and negatively charged peptides to the surface of gold nanoparticles. Toward this end, we investigated whether SERS would be capable of detecting unlabeled and weaker binding peptides on the gold surface. The P46 peptide sequence was chosen because its binding to gold was undetectable at neutral $\mathrm{pH}$ and it also contained four copies of an amino acid with a large Raman cross-section whose spectrum is well characterized (F). A gold-silica nanoshell substrate was used for the SERS studies, as the electromagnetic field surrounding gold nanoshells is stronger and the SERS effect was more reproducible than the gold colloid using a 785-nm excitation laser source [26]. The substitution of nanoshells for the colloid is valid because gold-silica nanoshells are also negatively charged as synthesized and behaved similarly to colloid in flocculation experiments with the P44 and P45 peptides (Fig. 5), except the degree of flocculation was reduced for the nanoshell solutions for equal amounts of peptide as determined by the decrease in the plasmon resonance at $785 \mathrm{~nm}$ (inset).

Clearly visible in the SERS spectrum of P46 (Fig. 6b) is the approx. 1,001 $\mathrm{cm}^{-1} \mathrm{C}-\mathrm{C}$ symmetric ring stretch attributable to the presence of $F$ [27]. As this band is the strongest band in the spontaneous Raman spectrum of P46 (Fig. 6a) and P46 contains four $\mathrm{F}$ residues, this band is an excellent marker for the presence of P46 on the surface of the gold nanoparticles. This clearly demonstrates that SERS can be used to detect the presence of unlabeled GBPs on the surface of gold nanoshells. In future studies, solutionphase SERS of P46 and other peptides will be used to study peptide surface coverage on the gold nanoparticle surface and for the detection of those specific amino acids that are responsible for the gold-peptide interaction.

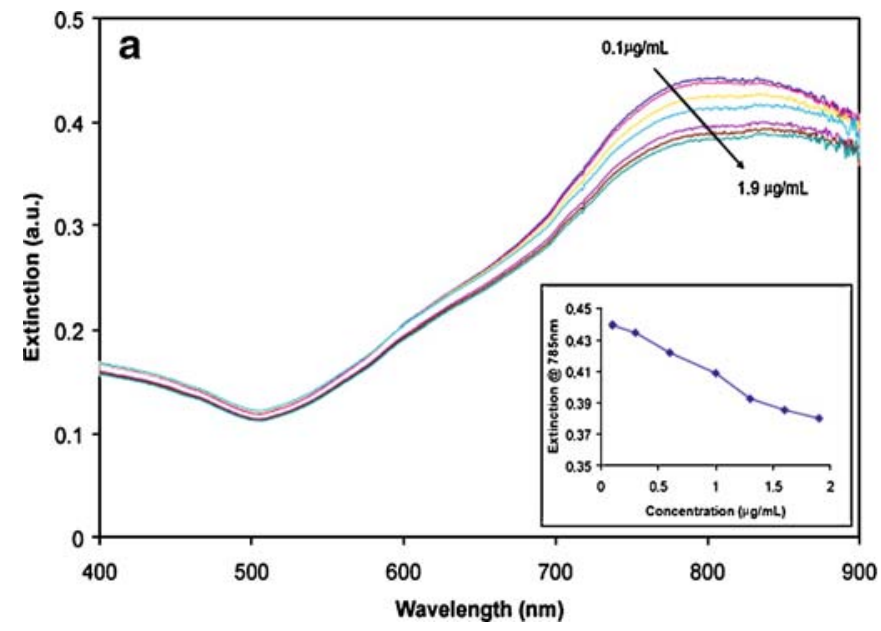

Fig. 5 UV-Vis spectroscopy of gold-silica nanoshells with P44 and P45 peptides. Wavelength vs extinction (absorption plus scattering) for gold-silica nanoshells with varying concentrations of P44 (a) and
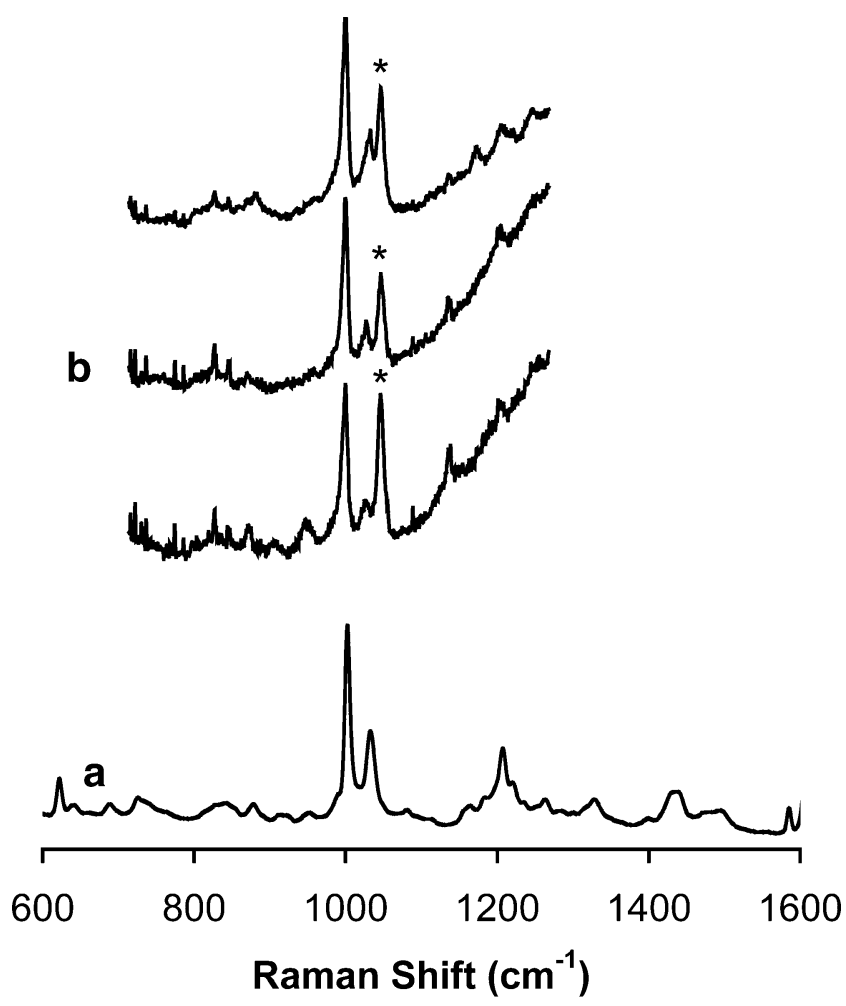

Fig. 6 Detection of P46 using Raman spectroscopy. a Spontaneous Raman spectrum of solid P46. b SERS spectra of P46 $(10 \mu \mathrm{g} / \mathrm{mL})$ on a gold nanoshell-based SERS substrate. Asterisk, band found in background spectra (wells incubated with buffer only)

\section{Conclusions}

In this study, SPR shifts, TEM, and DLS are used to investigate the degree of aggregation of gold nanoparticles upon the addition of GBPs. We have observed that the aggregation of the gold colloid is the result of the reduction in the electrostatic repulsion of gold colloids. The degree of aggregation can be controlled by controlling the surface

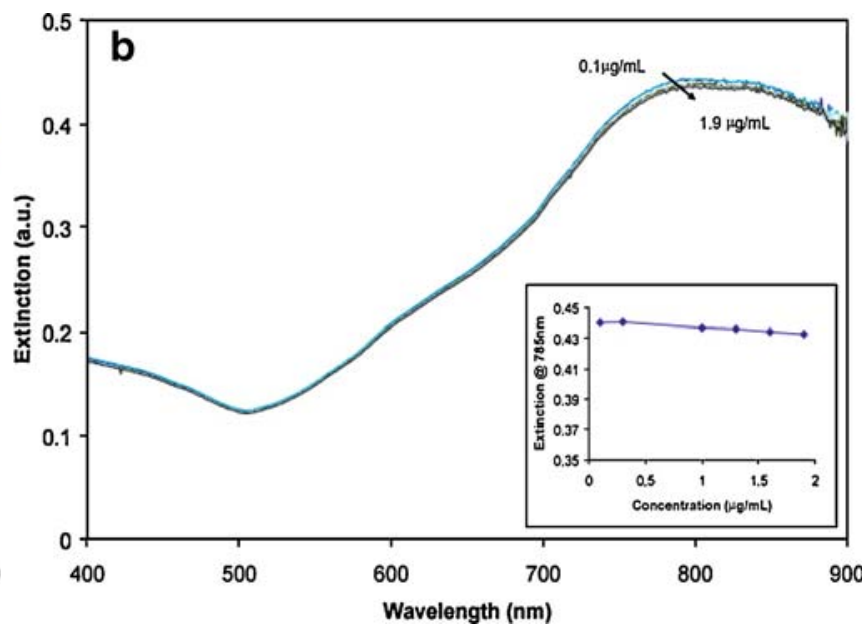

P45 (b) peptide. Inset: Extinction of nanoshells at $785 \mathrm{~nm}$ as a function of concentration of peptide 
coverage of peptide on the particle surface. Our results also indicate that the control over $\mathrm{pH}$ can control the degree of ionization of adsorbed peptides, which can be used to tailor the degree of aggregation. Further studies are underway to determine whether the peptide coverage on gold nanoparticles changes as a function of $\mathrm{pH}$. We have shown that these peptides have a similar effect on gold-silica nanoshells. Nanoparticle substrates containing gold-silica nanoshells were used to detect the binding of the P46 peptide using SERS. These results suggest that future SERS studies may be useful for the detection of unlabeled GBPs on the surface of gold nanoparticles and may also find applications in understanding the orientation of GBPs on gold surfaces in solution and help elucidate charge-independent binding mechanisms.

Acknowledgment We acknowledge helpful discussions with Prof. Victor Perez-Luna regarding this topic. We also thank Dr. Andy Paszkowski at Precision Colloid, LLC (Cartersville, GA) for helpful discussions and providing a sample of silica cores (Nanosol ${ }^{\mathrm{TM}}$ 30100D). All transmission microscopy results were obtained by Mr. John Roth at the Research Resource Center at the University of Illinois at Chicago. We thank the Illinois Institute of Technology College of Science and Letters for financial support.

\section{References}

1. Brown S (1992) Engineered iron oxide-adhesion mutants of the Escherichia coli phage 1 receptor. PNAS 89:8651-8655

2. Peelle BR et al (2005) Design criteria for engineering inorganic material-specific peptides. Langmuir 21:6929-6933

3. Whaley SR et al (2000) Selection of peptides with semiconductor binding specificity for directed nanocrystal assembly. Nature 405:665-668

4. Lee S-W et al (2002) Ordering of quantum dots using genetically engineered viruses. Science 296:892-895

5. Sarikaya M et al (2004) Materials assembly and formation using engineered polypeptides. Ann Rev Mat Res 34:373-408

6. Willett RL et al (2005) Differential adhesion of amino acids to inorganic surfaces. Proc Natl Acad Sci USA 102:7817-7822

7. Storhoff JJ et al (2000) What controls the optical properties of DNA-linked gold nanoparticle assemblies? J Am Chem Soc 122:4640-4650

8. Su KH et al (2003) Interparticle coupling effects on plasmon resonances of nanogold particles. Nano Lett 3:1087-1090
9. Aslan $\mathrm{K}$ et al (2004) Tunable plasmonic glucose sensing based on the dissociation of con A-aggregated dextran-coated gold colloids. Anal Chim Acta 517:139-144

10. Liu J, Lu Y (2004) Accelerated color change of gold nanoparticles assembled by DNAzymes for simple and fast colorimetric $\mathrm{Pb} 2+$ detection. J Am Chem Soc 126:12298-12305

11. Thaxton CS et al (2006) Gold nanoparticle probes for the detection of nucleic acid targets. Clin Chim Acta 363:120-126

12. Stevens MM et al (2004) Coiled-coil peptide-based assembly of gold nanoparticles. Adv Mat 16:915-918

13. Baker GA, Moore DS (2005) Progress in plasmonic engineering of surface-enhanced Raman-scattering substrates toward ultratrace analysis. Anal Bioanal Chem 382:1751-1770

14. Moskovits M (1985) Surface-enhanced spectroscopies. Rev Mod Phys 57:783-826

15. Levin CS et al (2006) Determining the conformation of thiolated poly(ethylene glycol) on $\mathrm{Au}$ nanoshells by surface-enhanced Raman scattering spectroscopic assay. Anal Chem 78:3277-3281

16. Turkevich J et al (1953) The formation of gold colloid. J Phys Chem 57:670-673

17. Voet D, Voet J (1995) Biochemistry. Wiley, New York

18. Oldenburg SJ et al (1998) Nanoengineering of optical resonances. Chem Phys Lett 288:243-247

19. Slocik JM et al (2002) Monoclonal antibody recognition of histidine-rich peptide encapsulated nanoclusters. Nano Lett 2:169-173

20. Bellino MG et al (2004) Adsorption kinetics of charged thiols on gold nanoparticles. Phys Chem Chem Phys 6:424-428

21. Myers D (1999) Surfaces, interfaces, and colloids: principles and applications. Wiley, New York

22. Aili D et al (2006) Aggregation-induced folding of a de novo designed polypeptide immobilized on gold nanoparticles. J Am Chem Soc 128:2194-2195

23. Levy R et al (2004) Rational and combinatorial design of peptide capping ligands for gold nanoparticles. J Am Chem Soc 126:10076-10084

24. Hopp TP, Woods KR (1981) Prediction of protein antigenic determinants from amino acid sequences. Proc Natl Acad Sci USA 78:3824-3828

25. Kirk JS, Bohn PW (2004) Surface adsorption and transfer of organomercaptans to colloidal gold and direct identification by matrix assisted laser desorption/ionization mass spectrometry. J Am Chem Soc 126:5920-5926

26. Jackson JB, Halas NJ (2004) Surface-enhanced Raman scattering on tunable plasmonic nanoparticle substrates. Proc Natl Acad Sci 101:17930-17935

27. Stewart S, Fredericks PM (1999) Surface-enhanced Raman spectroscopy of peptides and proteins adsorbed on an electrochemically prepared silver surface. Spectrochim Acta Part A $55: 1615-1640$ 